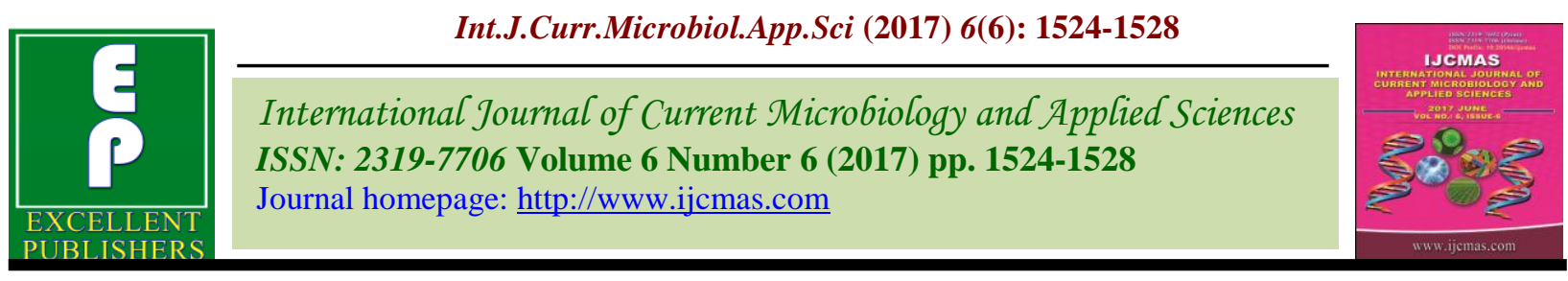

Review Article

https://doi.org/10.20546/ijcmas.2017.606.179

\title{
Mycofiltration: A Step Towards Sustainable Environment
}

\author{
Abhimanyu Mehta*, Reena Dubey and Sumit Kumar \\ G.B. Pant University of Agriculture and Technology, Pantnagar - 263145 (Uttarakhand), India \\ *Corresponding author
}

\begin{tabular}{|c|c|}
\hline & A B S T R A C T \\
\hline & \multirow{5}{*}{$\begin{array}{l}\text { The purposeful utilization of the vegetative development of mushroom- } \\
\text { framing parasites on wood mulch substrates as a naturally dynamic } \\
\text { filtration media, a procedure known as mycofiltration, is a promising new } \\
\text { innovation for improving biofiltration of storm water, gray water, and } \\
\text { agricultural spillover. Late trials have recorded that Escherichia coli can be } \\
\text { selectively removed from sullied water around } 20 \% \text { for each cubic foot } \\
\text { more successfully by mycofiltration than by wood mulch alone. This } \\
\text { change in microbe's evacuation was consistent even after introduction of } \\
\text { the mycofiltration media to cruel natural conditions such as - } 15 \text { to } 40{ }^{\circ} \mathrm{C}(5 \\
\text { to } 140{ }^{\circ} \mathrm{F} \text { ) temperature extremes. This article clearly depicts the major } \\
\text { important role of biofilteration in ensuring the water quality for sustainable } \\
\text { environment system. }\end{array}$} \\
\hline Keywords & \\
\hline $\begin{array}{l}\text { Mycofiltratin, } \\
\text { Environment, } \\
\text { Biofilteration, } \\
\text { Water. }\end{array}$ & \\
\hline Article Info & \\
\hline $\begin{array}{l}\text { Accepted: } \\
\text { 21 May } 2017 \\
\text { Available } \\
\text { Online: } \\
\text { 10 June } 2017 \\
\end{array}$ & \\
\hline
\end{tabular}

\section{Introduction}

Mushroom-shaping parasites are principally earthbound, high-impact living beings whose vegetative development appears as a mind boggling and dynamic three-dimensional web of tube-like cells called mycelium. The utilization of the mycelium of select individuals from the kingdom of organisms for numerous applications in bioremediation (a procedure on the whole called "parasitic bioremediation" or" mycoremediation") has been settled. Many mushroom-framing growths of the phylum basidiomycota, which incorporates surely understood species, for example, the clam mushroom (Pleurotus ostreatus) and turkey tail mushroom (Trametes versicolor) are further described as "white decay," a casual characterization named for the white cellulose-rich material that is deserted as these life forms metabolize the lignin from their wood substrate. The capable lignin-debasing proteins created by these white-decay basidiomycetes-most eminently laccase, lignin peroxidase, and manganese peroxidase - are equipped for cocorrupting a various suites of headstrong synthetic contaminants. Curiously, a few of these compound corrupting species are likewise known to originate before microorganisms, create intense anti-infection metabolites, and are broadly become monetarily because of their simplicity of development on a wide assortment of substrate materials. The fuse of these creatures into designed water treatment 
biological systems and biofiltration media have shown changes in microscopic organism's diminishments both in the lab and at scale. This archived application, among a few others under scrutiny, can give ecological specialists, water quality experts and nursery chiefs with another instrument for upgrading natural water treatment frameworks. Basic lab explore supporting the utilization of wood and leaf litter corrupting organisms for natural administrations has been generally established in the more extensive setting of mycoremediation. Enthusiasm for mycoremediation expanded significantly in the mid-1980s after the revelation of the catalyst lignin peroxidase in the white-decay basidiomycete Phanerochaete chrysosporium. Fungi could even be developed utilizing eliminated microscopic organisms as the sole supplement source. Quite a long while later, observed that some normal and even culinary basidiomycetes such as the catch mushroom (Agaricus brunnescens $=$ A . bisporus), oyster mushroom (Pleurotus ostreatus), blewit (Lepistanuda), and the flaky ink top (Coprinus quadrifidus) are equipped for searching out and originating before living settlements of microorganisms (Agrobacterium tumefaciens and Pseudomonas putida) as wellsprings of sustenance. This work supplemented past review recording that Pleurotus ostreatus can likewise deaden and devour nematodes. This microscopic organisms originating before highlight was one of a kind to basidiomycetes and happened in just four of the approximately 100 phylogenetically assorted contagious culture that were screened. The term mycofiltration - characterized as the utilization of deliberately developed systems of parasitic mycelium to encourage water quality changes in built biological communities-first shows up in the writing in 1993. Related ideas, for example, the utilization of parasitic bioreactors were examined as ahead of schedule as 1969 for decolorizing Kraft fade plant emanating, and all through the 1980s utilizing gel immobilized fractionated mycelium for wastewater treatment. The consolidation of growths into open air biofiltration frameworks, be that as it may, started when we placed' garden mammoth' (Strophariarugoso annulata) mushroom bed reduced bacteria overflow from upland field.

\section{Mycofilteration and its application}

Mushrooms: most trust they are immaterial timberland development and a minor nourishment source in individuals' eating methodologies. Be that as it may, these little living beings have enormous potential packaged up in their systems of roots. A mushroom's underlying foundations, or mycelia, complete regular procedures fit for ecological remediation. Mycelia are made out of a mass of string like structures called hyphae. The hyphae shape thick, extensive systems underground that retain supplements in the dirt by emitting catalysts. Their enzymatic and retention capacities make growths an extraordinary contender for a few techniques for remediation, or mycoremediation, the term used to portray the procedure of parasites gaining and corrupting poisons in the earth through their mycelia. Since mycoremediation wears many caps, mycelia can be utilized as natural channels, wipes for poisons, and strengtheners of soil. The filtration part of mycelia, or mycofiltration, has been generally contemplated as a technique to sanitize storm water. In one review, the contagious animal varieties $S$. rugosoannulata demonstrated to expel up to $20 \%$ of $E$. coli particles from tempest water. E. coli microscopic organisms are regularly safe however a few strains have been known to bring about disease. Other than being a conceivable reason for sickness, $E$. coli is viewed as a pointer for fecal defilement in water. The evacuation of these 
microorganisms is appropriate to groups wherever as all people require sterile water. The review set up tests to pour debased tempest water through the characteristic channel. The parasite was added to two distinct substrates. Three holders encased birch wood chips-one without the growth, one with the organism, and one with the parasite after "vivacious testing" (organism put through a few outrageous temperature changes). Two compartments encased a blend of $75 \%$ birch chips and $25 \%$ rice straw-one without the organism, and one with nonenergetically tried parasite. These specimens were imitated three circumstances for an aggregate of fifteen compartments. The tempest water was permitted to go through the channels and tests were gathered after various time interims. The best achievement was a $20 \%$ reduction in $E$. coli focus in the specimens with non-vivaciously tried growth on $100 \%$ wood chips. The outcomes were measurably critical when contrasted with the control. These outcomes likewise recommend from the accomplishment of the enthusiastically tried growth that in brutal conditions, S. rugosoannulata mycelium can evacuate E. coli. This proposes the safe way of growths and its capacity to remediate in cruel conditions. Further demonstrating the resistance of organisms, a review closed the capacity of Irpex lacteus and Pleurotus ostreatus species to expel polycyclic fragrant hydrocarbons (PAHs) from soil. PAHs are cancer-causing poisons transmitted from industry. PAHs are of awesome wellbeing concern; they can bring about skin and insusceptible framework harm and in addition advance tumor generation. These toxins are hard to cleanup; they remain in the earth for quite a while and don't separate in water. Accordingly, mycelia offer an effective, green technique for the expulsion of these hurtful chemicals. This review concentrated on two types of parasites, Irpex lacteus and Pleurotus ostreatus, and two sorts of soils, a zone with a previous tar-delivering plant (An) and a saved lush territory without the tar-creating plant (B). The dirts were set between two layers of mycelium on straw. There were six examples of each dirt/organism mix and results were measured following 14 weeks of development. For soil An, Irpex lacteus had fundamentally expelled more PAHs from the dirt than Pleurotis ostreatus. Soil B indicated comparable outcomes for both species. Of course, Soil An's organisms expelled more PAHs than Soil B (Bhatt). PAHs are found in tar stores so soil A had more PAHs accessible for expulsion. These species displayed biodegradation capacities in which parasites emit proteins through their hyphae to separate contaminations and poisons. In correlation, both reviews dove into the biodegradation capacities and resistance of organisms. Likewise, both reviews delivered huge aftereffects of poison expulsion when contrasted with control. Plainly, more trials and tests would support up the outcomes and finishes of both trials. Be that as it may, there are some contrasting qualities and shortcomings when looking at the outcomes. The review on PAH expulsion considered satisfactory development of the mycelia, though learn about E. coli mycofiltration did not. The amplified time of development (14 weeks) in the PAH concentrate strengthened the outcomes and added solidness to the analysis. The E. coli study was subjected to debilitated, less precise outcomes because of juvenile, temperamental mycelia societies. Then again, the E. coli ponder demonstrated quality as it was more up and coming than the $\mathrm{PAH}$ examine. The E. coli examine, finished for the current year, utilized more present methodologies and innovation. The scientists study's outcomes might be obsolete in the realm of science where information is corrected and quickly extended each moment.

Notwithstanding evacuating cancer-causing agents, examines have been led and have 
inferred that organisms can separate raw petroleum. In one review, the impacts of a biologically built framework (EES) on an oilsullied stream were measured. The exploration occurred at a stream in Fishersville Mill. This waterway is debased by a huge number of gallons of Bunker $\mathrm{C}$ raw petroleum. The EES was involved three progressive "channels" made out of four anaerobic microbial species, four mycelium species, and five plant species. While the outcomes are less convincing with the incorporation of other separating life forms, there is confirmation to propose that mycelia have unrefined petroleum corrupting capacities. In the review, the centralizations of petroleum hydrocarbons (PAHs and aliphatic hydrocarbons) were measured after EES treatment utilizing mass spectrometry. In mass spectrometry, a specimen is barraged with electrons, breaking the particles into charged particles. The particles are isolated by mass, which is utilized to recognize and decide the centralization of the atom. The defiled water was gone through the microscopic organism's channel, then the mycelia channel, and after that the plant channel. The water was inspected at the diverse stages occasionally for five months. For aliphatic hydrocarbons, organisms decreased focus after microscopic organism's filtration by $5.2 \%$. The whole framework decreased aliphatic hydrocarbon fixation all things considered by $95.2 \%$ from the pattern. For PAHs, growths decreased fixation after microorganism's filtration by $67.1 \%$. The EES diminished PAH focus all things considered by $91 \%$ from the benchmark. Both normal decreases in PAH and aliphatic hydrocarbon fixations were thrown off by the plant channel treatment which really expanded hydrocarbon focuses by $22.4 \%$ and $58.4 \%$ individually. This expansion may have been brought about by vanishing that diminished water volume therefore expanding groupings of poisons in respect to the measure of water. In general, the outcomes proposed a huge decline in contaminants when contrasted with the control of unfiltered water. This article shows the impact of utilizing growths couple with other bioremediating life forms. The consolidating endeavors of bioremediating life forms can create broadly material outcomes for some conditions if more research is led.

Not exclusively are organism's abundant filterers and safeguards, they are additionally adequate soil retainers. Soil quality can be enhanced with the acquaintance of organisms with a region. A review was led on the rigidity (most extreme measure of stress that can be withstood) and scraped area resistance (capacity to oppose disintegration) of soil with and without various types of mycelia. The review tried types of growths on sandy earth soil with and without glucose. Six species and a control without growth were tried for every treatment. The types of growths delivered noteworthy contrasts in soil dependability and quality when contrasted with the control. Additionally, the soil with glucose had higher resistance and quality than the plain topsoil with indistinguishable types of parasites from the glucose filled in as vitality and wellspring of development for the mycelia. The hyphae of the growths species framed distinctive shapes and hangs on soil particles however the general outcomes continued as before. The outcomes propose that the steadiness of the dirt was specifically identified with the quality of the dirt. The hyphae could clutch soil particles and increment the rigidity. The mycelia's hold on soil withstood more weathering and twist disintegration than plain soil. As usual, the investigation ought to be rehashed for affirmation. Be that as it may, this examination applies to the whole globe: undesirable soil coordinated with wind disintegration spreads toxins and does not productively sequester carbon. Sound soil can 
assimilate more carbon, decreasing the nursery impact issue.

\section{Steps to clean river through mycofilteration}

$40 \mathrm{~kg}$ of mushroom spawns are carefully weighed out to the correct portions needed per sack.

Several locally sourced straw bales were acquired from Farm.

Freshly chipped wood sourced were collected from the native deciduous forest.

All the materials needed: straw, wood chip, sacks, mycelium spawn and a plentiful supply of fresh water were laid out and are scooped inside bag.

The ingredients were layered like a special lasagne: first a good layer of wet straw then wooden chips and finally a generous sprinkling of mycelium was added and the layering process repeated, until the bags were tightly packed and full.

After five weeks typically, the mycelium had grown throughout the sacks and was visible on the outside as a white feathery network of filament.

Finally these bags were installed in different water sites for final testing.

The mycofilters will now be monitored regularly, with water and silt samples sent away for analysis.

In conclusion, the purposeful use of organisms in the earth for natural administrations that bolster human needs and remediate past human impacts has been entrenched as a biologically sane approach. While much work stays to be done in deciding best application practices and characterizing treatment parameters, organizing learning furthermore, ability sets between mushroom cultivators, ecological researchers furthermore, approach producers sets the phase for across the board usage of mycofiltration techniques sooner rather than later. As this imperative assemblage of examine progresses, the purposeful consolidation of organisms in natural building configuration may one day get to be as typical as the planting of cattails in built wetlands is today. One might think: Humanity has discovered its panacea! Not exactly. While there are demonstrated remediation capacities in mycelium, additionally study is required. Research is restricted to a current surge in enthusiasm for remediating properties of organisms. More outcomes should be led before projects for mycoremediation are established. All in all, mycoremediation is an instrument that merits expanded thought. Both field and lab tests utilizing thorough factual investigation give prove that mycofiltration might be utilized viably as method for remediation of fecal contaminated water streams. Advance examination is required to decide the wellspring of variety when utilizing mycofiltration methods.

\section{References}

Adamovic, M., G. Grubic, I. Milenkovic, R. Jovanovic, R. Protic, L. Strenovic, and L. Stoicevic. 1998. The biodegradation of wheat straw by Pleurotus ostreatus mushrooms and its use in cattle feeding. Anim. Feed Sci. Technol., 71930: 357-62.

Adekunle, I.M., Adetunji, M.T., Gbadebo, A.M. and Banjoko, O.B. 2007. Assessment of ground water quality in a typical rural settlement in Southwest Nigeria, Int. J. Environ. Res. Public Health, 4(4): 307318.

Agbaire, P.O. and Obi, C.G. 2009. Seasonal variations of some physico-chemical, Properties of River Ethiope Water in 
Abraka, J. Appl. Sci. Environ. Manage., 13(1): $55-57$.

Akpaja, E.O., Kesiena, C.G. and Okhuoya, J.A. 2014. Mycofiltration potential of Pleurotus florida (Mont.) Singer on cassava mill effluent. Biological and Environmental Science, J. Tropics (BEST), 11(3): 191-200.

American Public Health Association (APHA) 1998. Standard Methods for the Examination of Water and Wastewater (18 edn.). Washington DC: American Public Health Association, pp. 45-60.

Anonymous. 2004. A world ruled by fungi. Terra Daily March 08, 2004. Source: Swedish Research Institute.

Aust, S.D. 1990. Degradation of environmental pollutants by Phanerochaete chrysosporium. Microbial Ecol., 20: 197209.

Baker, Richard, W. 2004. Membrane Technology and Applications. Wiley, New York.

Barron, G.L. 1988. Microcolonies of bacteria as a nutrient source for lignicolous and other fungi. Can. J. Bot., 66: 2525- 2510.

Barron, G.L., Thorn, R.G. 1987. Destruction of nematodes by species of Pleurotus. Bot., 65(4): 774-778.

Battelle Environmental Updates. "Mushrooms: Higher Macrofungi to Clean Up the Environment.

Bending, G.D., Friloux, M., Walker, A. 2002. Degradation of contrasting pesticides by white rot fungi and its relationship with ligninolytic potential. FEMS Microbiol. Lett., 212(1): 59-63.

Beutel, M., Flatt, A., Taylor, A., Wolff, M., Neira, L., Wolff, M., Brownson, K., Stamets, P. 2002. Removal of Escherichia coli from synthetic storm water using mycofiltration. Ecol. Eng.

Bhatt, M. 2002. Mycoremediation of PAHcontaminated soil. Folia microbiologica Academia Scientiarum Bohemoslovaca, 255-258.

Bhatt, M.T., Cajthaml, V., Sasek. 2002. Mycoremediation of PAH-contaminated soil. Folia Microbiologica, 47: 255-258.
Booth, D., Visitacion, B., Steinemann, A. 2006. Damages and costs of stormwater runoff in the Puget Sound region. The Water Center, University of Washington.

Bumpus, J.A., Tien, M., Wright, D., Aust, S.D. 1985. Oxidation of persistent environmental pollutants by a white rot fungus. Science, 228: 1434-1436.

Claaasen, H.C. 1982. Guidelines and Techniques for Obtaining Water Samples that Accurately Represent the Quality of an Aquifer (49 p). US Geol. Surv. Open File Report, 82-1024.

Curl, E.A. 1986. The Rhizosphere. Berlin: Springer-Verlag.

Daniels, Russell James. Nitrous Oxide Emissions of Higher Fungal Mycelium under various Wastewater Concentrations. Order No. 1534032 State University of New York College of Environmental Science and Forestry, Ann. Arbor. Pro Quest.

Edwards, Andres, R. 2005. The Sustainability Revolution: Portrait of a Paradigm Shift. New Society Publishers, Gabriola Island, Canada.

Elekes, C.C., Busuioc, G., and I.R.C. 2010. The Mycoremediation of Metals Polluted Soils Using Wild Growing Species of Mushrooms. Eng. Edu., pp. 36-39.

Erwin, D.H. 1993. The Great Paleozoic Crisis: Life and Death in the Permian. Columbia University Press, New York.

Fulekar, M.H. and Pandey, B. 2012. Bioremediation technology: a new horizon for environmental clean-up. Biol. Med., 4(1): 51-59.

Gorder, P.R. 2006. Big Bang in Antarctica: killer crater found under ice. Research News (June 1, 2006). Ohio State University.

Halberg, N. 2005. Farm level environmental indicators; are they useful? An overview of green accounting systems for European farms. Agri. Ecosystems Environ., 105(12): pp. 195-212. doi: 10.1016/j.agee.2004.04.003. 
Hobbs, C. 1995. Medicinal Mushrooms: An Exploration of Tradition, Healing, and Culture. Santa Cruz, CA: Botanica Press.

Jaramillo, L., C. Rodríguez, and V.S.T. Chang. 2004. Cultivation of Shiitake in Coffee Waste. www.scizerinm.org/ mushrooms.html.

Kulshreshtha, Shweta. 2014. Mushroom as a product and their role in mycoremediation. AMB Express, 4(1): 17.

Leung, M. 2004. Bioremediation: techniques for cleaning up a mess. Biotech. J., 2: 18-22.

Maanen, J.M.S.V.A.N., Vaan, M.A.J.D.E., Veldstra, A.W.F., and Hendrix, W.P.A.M. 2000. Pesticides and nitratre in groundwater and rainwater in the province of limburg in the Netherlands. Environ. Monitoring and Assessment, pp. 95-114.

Mihara, H., H. Sumi, T. Yoneta, H. Mizumoto, R. Ikeda, M. Seiki, and M. Maruyama. 1991. A novel fibrinolytic enzyme extracted from the earthworm, Lumbricusrubellus. Japan J. Physiol., 41(3): 461-72.

Monastersky, R. 1996. Global crisis: The fungi standalone - mass extinction at the end of the Permian period. Sci. News, 149: 1644.

Mshigeni, K., and G. Pauli. 1997. Brewing a future. Yes! Magazine. Summer 1997 issue.

www. futurenet.org/article.asp?ID=890.

National Center for Environmental Innovation. 2005. U.S. Environmental Protection Agency.

Nduka, J.K.C. and Orisakwe, O.E. 2010. Precipitation chemistry and occurrence of Acid rain over the oil-producing Niger Delta Region of Nigeria. The Scientific World J., 10: 528-534.

New York Times. "Two Novel Solar Firms Nab Venture Funds."

Nowak, R. 2002. New Hong Kong law tackles killer flu fear, New Scientist, 12: 17.

Okuo, J.M., Akpaja, E.O. and Eguono, W.O. 2008. Kinetics of cadmium (II) and Selenium (IV) ions removal from aqueous solution by the fruiting bodies of white- rot Fungi (Pleurotus tuberregium). $J$. Chem. Soc. Nigeria, 33(1): 56-64.

Okuo, J.M., Akpaja, E.O. and Iyelenmeholo, A. 2009. Biosorption of cadmium (II) and selenium (IV) ions from aqueous solution by sclerotia of Pleurotus tuberregium (Fr.) Singer. Int. J. Chem., 1(1): 47-52.

Olson, Robert and Rejeski, David. 2005. Environmentalism and the Technologies of Tomorrow. Washington, D.C.: Island Press.

Onokerhoraye, A.G. 1995. Urbanization and Environment in Nigeria: Implications for Sustainable Development. The Benin Social Science, Series for Africa. Benin City: University of Benin.

Pauli, G. 1997. No Waste Economy. ReSurgence Magazine.

Pauli, G. 1999. Earthworms, mushrooms and zero waste in China. BioCycle, 40(2): 6869.

Pauli, G. 2002. World without waste: Technological solutions inspired by nature. ReSurgence Magazine Issue, 213 (July/Aug. 2002).

Prasad, A.S.A., Varatharaju, G., Anushri, C. and Dhivyasree, S. 2013. Biosorption of lead by Pleurotus florida and Trichoderma viride. British Biotechnol. J., 3(1): 66-78.

Robles-Hernandez, L., Gonzàlez-Franco, A.C., Crawford, D.L. and Chun, W.W.C. 2008. Review of environmental organopollutant degradation by white-rot basidiomycetes Mushrooms. Tecnociencia Chihuahua, 2(1): 32- 39.

Schroder, J. 2004. The effects of nutrient losses from agriculture on ground and surface water quality: the position of science in developing indicators for regulation. Environ. Sci. Policy, 7(1): pp. 15-23. doi: 10.1016/j.envsci.2003.10.006.

Sharma, S., Keshav, P.S. and Nand, K.S. 2010. Bioremediation: developments, current practices and perspectives. Genetic Eng. Biotechnol. J., 3: 1-20.

Singh, H. 2006. Mycoremediation: Fungal Bioremediation, John Wiley and Sons, Inc. New Jersey. p. 484-532. 
Singh, J.K., Meshram, R.L. and Ramteke, D.S. 2011. Production of single cell protein and removal of COD from dairy waste water. Eur. J. Exp. Biol., 1(3): 209-215.

Smith, Douglas, J. 2002. "Distributed Generation Coming Into Focus." Power Engineering.

Stamets, P. 1999. MycoMedicinals: An Informational Treatise on Mushrooms. Mycomedia.

Stamets, P. 2005. Mushroom magic: Oyster mushrooms cleaning up oil spillswhatever next? Resurgence Magazine, Issue 232.

Stamets, P. 2005. Mycelium Running: How Mushrooms Can Help Save the World. Ten speed Press, Berkeley, Toronto. Pp. 54- 64.

Stamets, P. 2005. Mycelium Running: How Mushrooms Can Help Save the World. Berkley/Toronto: Ten Speed Press (15 Oct. 15, 2005).

Stamets, P.E. 2003. Delivery systems for mycotechnologies, mycofiltration and mycoremediation. Publication number: US 2005/0176583 A1.

Stamets, Paul. 1999. Mycomedicinals: An Informational Treatise on Mushrooms. Myco Media.

Stamets, Paul. 2005. Mycelium Running. Ten Speed Press.

Standard Organisation of Nigeria (SON) 2007. Nigerian Standard for Drinking Water Quality. Lome Street, Abuja, Nigeria. $29 \mathrm{p}$.

Stapleton, Lisa. 2003. "Healing Nature with Nature: Given Time, Fungi Could Save the Day. Terrain.
Thomas, S., Becker, P., Pinza, M.R., and Word, J.Q. 1998. "Mycoremediation of Aged Hydrocarbon Contaminants in Soil." Battelle Marine Sciences Laboratory and Pacific Northwest National Laboratory.

U.N. Briefing Papers/The World Conferences: Developing Priorities for the 21st Century. 1997. 112 Pp.

United Press International. 2006. Poultry farmers to switch to mushrooms. Hong Kong.

United States Environmental Protection Agency (USEPA). 1996. National recommended water quality criteria-correction: EPA 822/Z-99-001. USEPA, Washington, DC.

Vajda, V., and S. McLoughlin. 2004. Fungal proliferation at the Cretaceous-Tertiary boundary. Sci., 303(5663): 1489.

Van der Heijden, M.G.A., J.N. Klironomos, M. Ursic, P. Moutoglis, R. Streitwolf-Engel, T. Boller, A. Wiemken, and I.R. Sanders. 1998. Mycorrhizal fungal diversity determines plant biodiversity, ecosystem variability and productivity. Nature, 396: 69-72.

Wired Magazine. April 29, 2004.

Wolf, J., Beusen, a, Groenendijk, P., Kroon, T., Rotter, R., and Vanzeijts, H. 2003. The integrated modeling system STONE for calculating nutrient emissions from agriculture in the Netherlands. Environ. Modelling Software, 18(7): pp. 597-617. doi: 10.1016/S1364-8152(03)00036-7.

World Health Organization (WHO). 2011. Guidelines for Drinking Water Quality (4th edn., 564 Pp). Geneva: World Health Organization.

\section{How to cite this article:}

Abhimanyu Mehta, Reena Dubey and Sumit Kumar. 2017. Mycofiltration: A Step Towards Sustainable Environment. Int.J.Curr.Microbiol.App.Sci. 6(6): 1524-1528. doi: https://doi.org/10.20546/ijcmas.2017.606.179 